International Journal of Management (IJM)

Volume 12, Issue 9, September 2021, pp. 93-100, Article ID: IJM_12_09_008

Available online at https://iaeme.com/Home/issue/IJM?Volume=12\&Issue=9

ISSN Print: 0976-6502 and ISSN Online: 0976-6510

DOI: https://doi.org/10.34218/IJM.12.9.2021.008

(C) IAEME Publication

Scopus Indexed

\title{
IMPACT OF DIGITALIZATION ON CUSTOMER BUYING DECISION
}

\author{
Rohit Kumar $^{1}$ and Dr Jai Jayant ${ }^{2}$ \\ ${ }^{1}$ Research Scholar, H.N-38 Sangam Vihar, Jmalpur Haridwar, India \\ ${ }^{2}$ Assistant Professor, Department of Management, \\ Himgiri Zee University, Dehradun, Uttarakhand, India
}

\begin{abstract}
People become stronger as a result of digitalization, which allows them to save both time and money. The digital world blurs the lines between countries and brings individuals closer together. There is no need to go to a store to purchase a product or service; all it takes is a single click. Organizations are developing strategies to reach out to potential customers using digital platforms, which make it simple for them to reach out to the largest number of people. Buyers may now simply compare products on the basis of quality and pricing. Customers' purchasing decisions are also influenced by product availability. This study show that how digitalization influence customer buying behaviour, this study focus on some factors (reliability of digital information, easy access of websites, online digital communication source) which play important role for influencing the customers for buying product through digital platform. This study was conducted in Haridwar (Jwalapur, Kankhal, Sidkul) and sample size was 50. A questionnaire was prepared and based on some factors which influence customer buying behaviour.
\end{abstract}

Key words: Digitalization, influencing factors, customers, Digital platform

Cite this Article: Rohit Kumar and Jai Jayant, Impact of Digitalization on Customer Buying Decision, International Journal of Management (IJM), 12(9), 2021, pp. 93-100. https://iaeme.com/Home/issue/IJM?Volume=12\&Issue=9

\section{INTRODUCTION}

Technology has changed the way businesses operate; now, businesses can reach out to a larger number of customers in less time while also saving money. Customers have more power in the digital era because they can compare products, verify quality, check pricing, and choose from a variety of payment choices. As a result, both businesses and customers benefit from digitalization. Some factors like reliability of digital information, easy access of websites, online digital communication source play important role for influence the customers for buying the product through digital platform. 
5 Stages of the consumer decision process

- Problem Recognition or Need Recognition.

- Information Search.

- Evaluation of Alternatives.

- Purchase Decision.

- Post-Purchase Evaluation.

There are 5 stages of customer buying decision, digitalization start work from $1^{\text {st }}$ stage when problem arise, it is easy to search information through digital platform and it save the time and money. Through digital platform customer can easily compare the product, check the quality, price etc and get the discounts, easy access of websites make it easy to make purchase decisions. Digital marketing is playing important role for the human beings. Through digital platform people can buy product or service. Digital platform is giving so many facilities to the customers through whom they can see the product, compare the product price wise, quality wise and order the product online and have so many payment options through which customer can pay and have credit facility. No need to go anywhere physically, customer can order from their homes, digital marketing save the time and money. If any customer wants any information regarding any product or service, no need to go anywhere, through one click customer can get all the information. Organisations can easily approach the potential customers through digital marketing and through this platform organisations can reach maximum no of customers. Now day's digital marketing is playing important role in whole world. With the help of one click, customer can approach anywhere in the world. No need to go physically at any shop for buying any product. Digital marketing is giving facilities to the customer for buying any product and service without going at any shop. Digital marketing is also facilitating the customer with many payment option and also provide the credit facility. Customer can compare the price of the product and service. Customer can check the review and comment before buying any product; customer can go through maximum product.

\subsection{Objective of the Study}

To examine the impact of digitalization on customer buying decision.

\section{REVIEW OF LITERATURE}

Mathew Johnson (2020), conclude that without a doubt, the corona virus has left its mark in the history books. The question marketers should be asking themselves is just how much will these change things? We are starting to realize the impact the virus has had on industries, but how will the innovative marketers of today adjust? One thing is certain- digital solutions should be at the top of the agenda for all businesses.

Silvius Stancliu, Riana Iren Radu (2020), the need to make the educational system more flexible and its preparation for completing face-to-face activities with the online version; the capacity of some companies from SME's group to adapt to the critical incidents and to identify market segments; the reappraisal of the national agro-food system (primary production agricultural, industrial processing and trade), national investments and governmental support measures. The agro-food market is dependent on imports, and the manifestation of some critical situations can destabilize the food supply of the population. The agricultural production is dependent from climatic conditions and the governmental investments in a national irrigation system are insignificant.

Dr. James Seligman (2020), concludes that understand the customer base and how they asses purchases of items in tough times. Allocate funds to least risk areas, redefine and push value and trust. 
Dr. Saraswathi Moorthy (2020), conclude that understanding the need to study the buying behavior of online shoppers especially during this world pandemic crises is very essential, as this can enable online retailers to offer better shopping experience in terms of hygiene and safety by maintaining social distancing which is of foremost importance. Also, enabling a better online shopping experience can definitely avoid consumers to step out of their house thereby curbing the virus to a great extent

Alok Kumar \& eT. All (2020), concluded that the youngsters are widely exists in this markets. They are interested and easily aware the relevant information terms and policies etc. most of the young consumers prefer beyond sales the products and service through online platform. it is easy mode for customers and customers are satisfied with digital marketing.

Nikhil Monga (2020) concluded that the social advertisement campaigns can be made more popular among youth by the ways like: the message/theme of the campaigns should be effective so as to mark a deep impression on the thought building process of youth. The celebrity who is casted in the ad campaigns must be appealing/ acceptable to the youth and should have a good public image. The message provided by the campaign should be clear by which campaigns are presented should build interests of people. The content is the central point of a campaign, if it is not shown in a subtle manner; the main aim of the campaign should not be defeated. The ads should be presented at appropriate time, in accordance with the need and the nature of the ads.

Sabyasachi Das gupta (2019) found that mega sales and social media have a favorable impact on creating positive review, which influences the evaluation of alternatives and subsequent purchase stage. It can be concluded that social media marketing is a crucial instrument for garment company web marketers to keep up with current fashion trends, announce sales, and, most importantly, produce good evaluations and word of mouth, as these are the most sought after reviews. One key point to remember is that any garment company should spend in developing a solid CRM (Customer Relationship Management) system.

Snehal Chincholkar (2017) stated that consumers choose websites that offer a variety of high-quality products, better prices and discounts, faster delivery, and after-sales services when buying online, according to the study. Based on demographic variables, females are more loyal to a website than males when it comes to website loyalty.

Veena Tripathi, (2016) investigate the 'Impact of Online Marketing on Indian Teenagers,' In India, the full potential of internet media has yet to be realized, but the foundation has already been laid and is growing at a rapid pace. Social media is playing an increasingly important role in delivering the influence of internet media on youth, and it has had a lot of success. Companies can use social media as a resource and to their advantage. However, for the debate to continue, there must be some restriction and control. Though social media has enormous promise, it should not be exploited to deceive teens through stealth marketing methods.

Girshwyn Reddy (2016) ascertained that the focus of the study was on digital marketing and its influence on customer decision-making. According to Tiago and Verissimo (2014), there has been little research on digital marketing from an organizational standpoint, necessitating this academic study. As a result, the research focused on the impact of digital marketing on customer decision-making from the perspective of retail organizations. As indicated, the retail industry has experienced sales growth, and Nike South Africa's shops have the ability to increase sales by reaching out to customers through digital platforms. The study's business need was to identify and analyse the impact of Nike Inc., Nike South Africa (Pty) Ltd, and their South African retailers' digital marketing strategies on consumer decision-making.

P. Ranjith. (2016) studied that In Trichy, researchers looked on the impact of digital marketing on customer purchase decisions. The main goal is to investigate customer awareness of digital marketing in Trichy. Another goal of the study was to look into the impact of digital marketing on purchasing decisions. The information was gathered using an online questionnaire 
from a sample of 50 people in the target area. The Chi-Square Test was performed to analyze the data. The Chi Square Test yields the following results: Customer happiness is tied to the influence of digital channels, not to a change of opinion in their purchasing decision. According to his research, the current study shows that the influence of digital channels does not support a change in customer opinion toward purchasing a product, but that digital channels will impact customer purchase opinions in the near future as there is a consideration for digital channels among customer

\section{METHODOLOGY}

This study was conducted in Haridwar (Jwalapur, Kankhal, Sidkul) and sample size was 50. A questionnaire was prepared and based on some factors which influence customer buying behaviour. Random sampling technique was used in data collection.

\section{Hypothesis}

H1: Reliability of digital information has positive impact on customer buying decision.

$\mathrm{H} 2$ : Influencing factors like quality, easy access of websites, price, product availability has a positive impact on customer buying decision.

\section{ANALYSIS \& HYPOTHESIS TESTING}

\subsection{Influencing Power of Information Source}

Table-1

\begin{tabular}{|c|l|c|c|}
\hline S.N & \multicolumn{1}{|c|}{ SOURCE } & RESPONSE & PERCENTAGE \\
\hline 1 & PRINT MEDIA & 8 & 16 \\
\hline 2 & TELEVISION & 10 & 20 \\
\hline 3 & ONLINE PLATFORM & 28 & 56 \\
\hline 4 & Word of mouth & 4 & 8 \\
\hline
\end{tabular}

Source-Field Survey

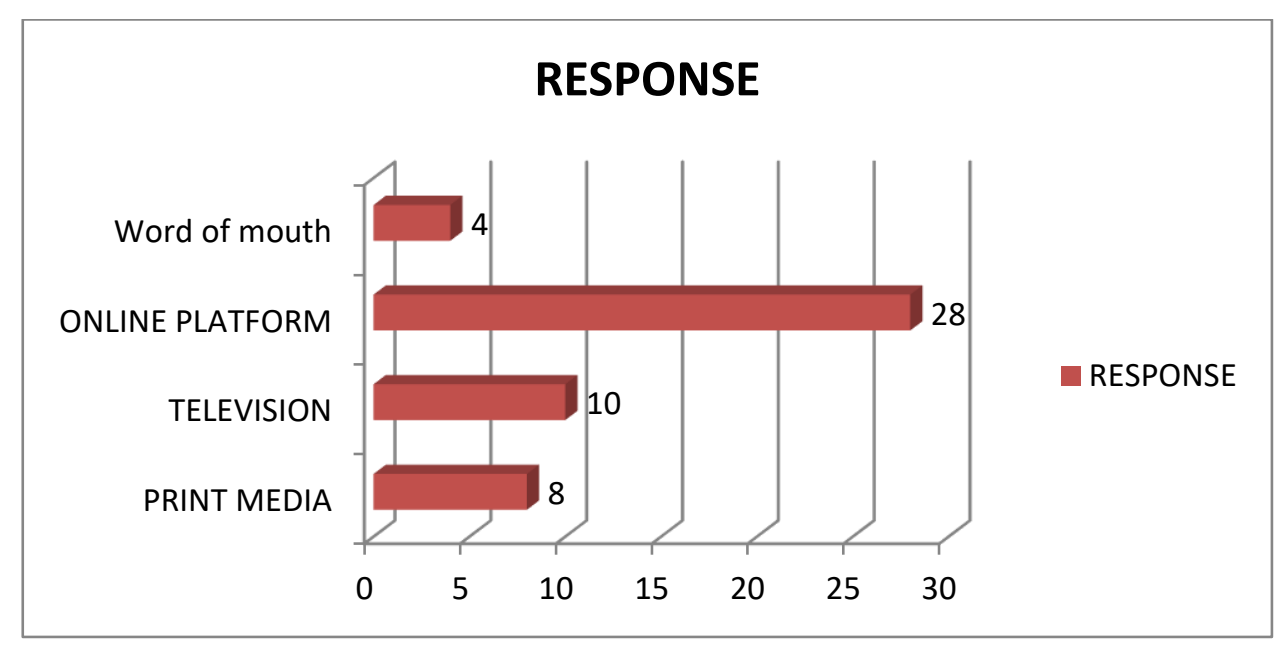

Figure 1

Table-1 shows that $56 \%$ respondent agree with influencing power of online platform, it means information available on online platform influence customer for buying any product or service. Digital information means advertisement, product or service information, campaign related to any product or service. $20 \%$ respondents agree with television and $16 \%$ respondents agree with print media. 


\subsection{Reliability of Online Information}

Table-2

\begin{tabular}{|c|c|c|c|}
\hline S.N & Reliability Of Digital Information & Response & Percentage \\
\hline 1 & YES & 34 & 68 \\
\hline 2 & NO & 16 & 32 \\
\hline
\end{tabular}

Source: Field survey

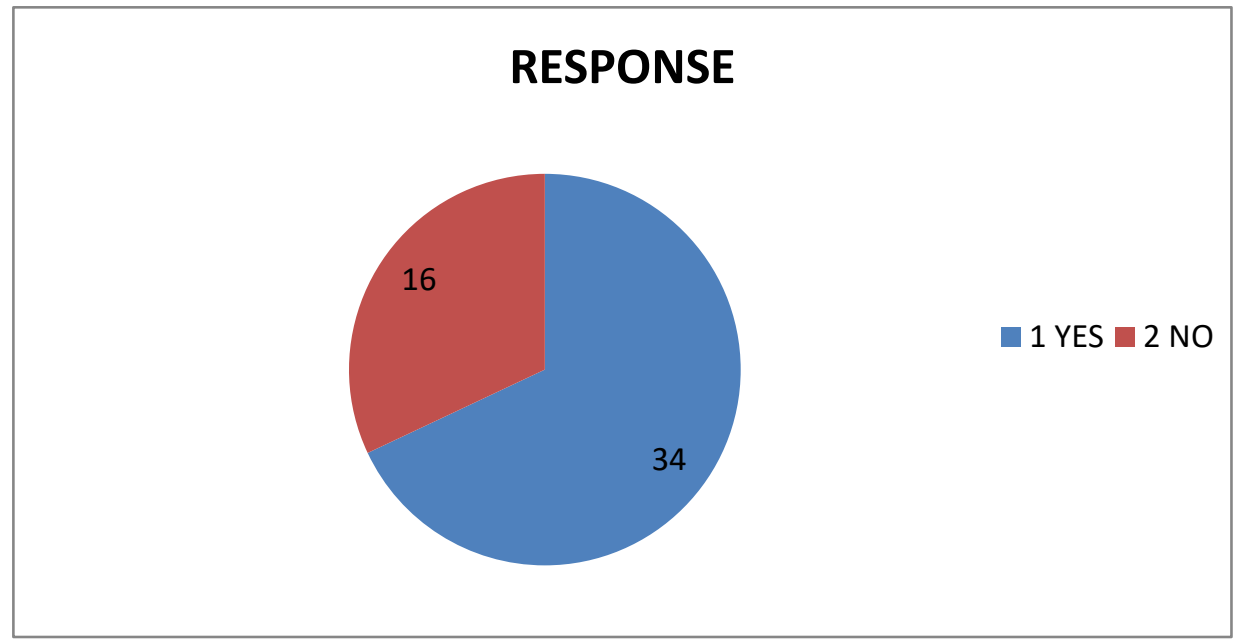

Figure 2

Hypothesis Testing: H1: Reliability of digital information has positive impact on customer buying decision.

\section{Calculation of Chi Square:}

Hypothesis Testing Table

Table 3

\begin{tabular}{|c|c|c|c|}
\hline \multicolumn{4}{|c|}{ Reliability of digital information has positive impact on customer buying decision. } \\
\hline & AGREE & DISAGREE & TOTAL \\
\hline OBSERVED(fo) & 34 & 16 & 50 \\
\hline EXPECTED(fe) & 25 & 25 & 50 \\
\hline
\end{tabular}

$\begin{array}{lrr}\text { fo-fe } & 09 & 09 \\ \text { fo-fe*fo-fe } & 81 & 81 \\ \text { fo-fe*fo-fe/fe } & 3.24 & 3.24\end{array}$

Chi square $=3.24+3.24=6.48$

$\mathrm{df}=(2-1)=1$

Levels of significance- .05

$\mathrm{p}$ value $=3.841$

Table- 2 shows that $68 \%$ respondents agree with reliability of online information, it means customers believe on online information and online information help customer for buying any product or service and obtained value of Chi square is greater than $p$ value it show the rejection of null hypothesis and acceptance of alternative hypothesis. So alternative hypothesis H1 is accepted, which state that reliability of digital information has positive impact on customer buying decision, has been proved, so hypothesis $\mathrm{H} 1$ is correct. 


\subsection{Influencing Power of Factors}

When this question was asked, one option was given to the customers that they can tick more than one option in this question

Table-4

\begin{tabular}{|c|l|c|}
\hline S.N & \multicolumn{1}{|c|}{ Factors } & Response \\
\hline 1 & Quality & 30 \\
\hline 2 & Easy Access Of Websites & 48 \\
\hline 3 & Price & 31 \\
\hline 4 & Availability Of Product & 49 \\
\hline
\end{tabular}

Source-Field survey

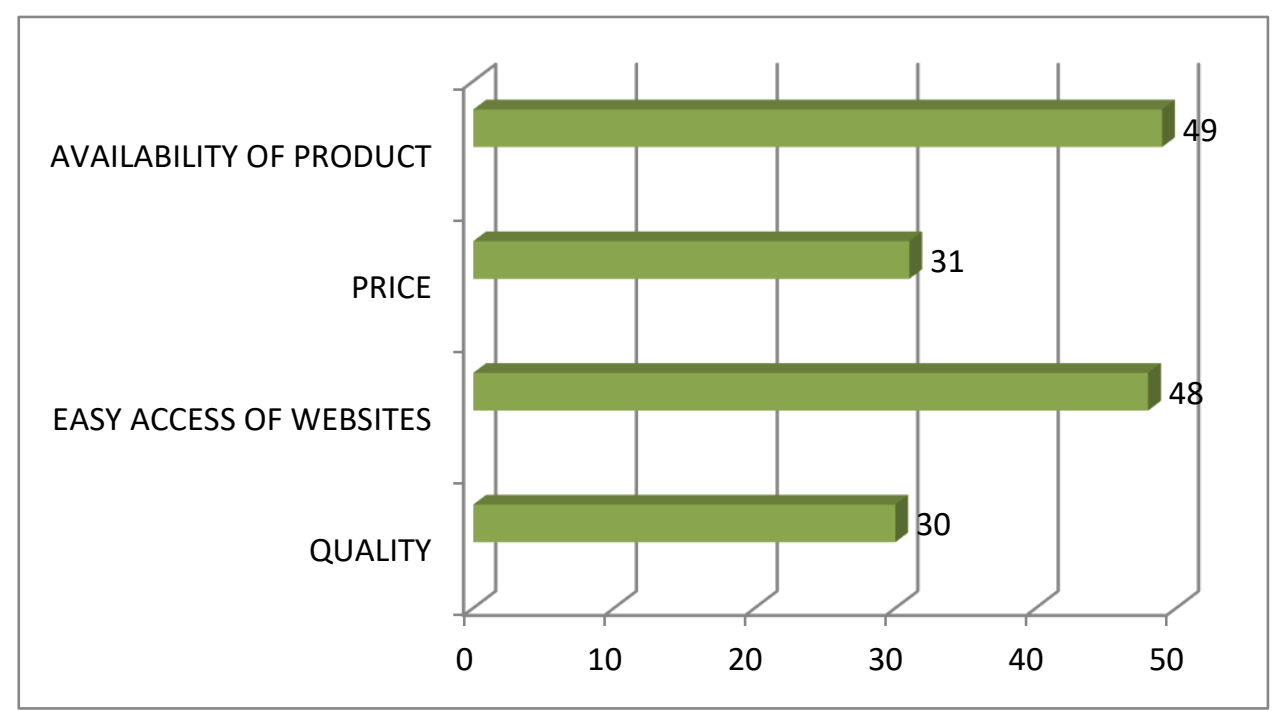

Figure 3

Hypothesis Testing H2: Influencing factors like quality, easy access of websites, price, and product availability has a positive impact on customer buying decision.

\section{Calculation of Chi Square}

\section{Hypothesis Testing Table}

Table 5

\begin{tabular}{|l|c|c|c|c|}
\hline Influencing Factors & $\begin{array}{c}\text { Response } \\
(\mathbf{X})\end{array}$ & Mean & Mean-Response & $\mathbf{( M - R}^{\mathbf{2}}$ \\
\hline Quality & 30 & 39.5 & 9.5 & 90.25 \\
\hline $\begin{array}{l}\text { Easy Access Of } \\
\text { Websites }\end{array}$ & 48 & 39.5 & 8.5 & 72.25 \\
\hline Price & 31 & 39.5 & 8.5 & 72.25 \\
\hline $\begin{array}{l}\text { Availability Of } \\
\text { Product }\end{array}$ & 49 & 39.5 & 9.5 & 90.25 \\
\hline
\end{tabular}

TOTAL- 325

\section{Chi Square}

$$
\chi^{2}-325 / 39.5=8.22
$$

Levels of significance- .05

Degrees of freedom $=n-1 \quad 4-1=3$ 
$\mathrm{P}$ value $=7.815$

It show $8.22>7.815$

Calculated value of chi square test is 8.22 greater than $p$ value 7.815 , it is indication of rejection of null hypothesis and acceptance of alternative hypothesis, so alternative hypothesis $\mathrm{H} 2$ is accepted that is easy access of websites has a positive impact on customer buying decision. When this question was asked, one option was given to the customers that they can tick more than one option in this question.

\section{CONCLUSION}

The objective of this study was to examine the impact of digitalization on customer buying decision. It was found that information available on online platform influence customer for buying any product or service, it means digital channels influence customer for buying any product or service. Customers believe on online information and online information help customer for buying any product or service. Chi square test was used in this study and for hypothesis $\mathrm{H} 1$ chi square value is 6.48 , which is greater than p value, so null hypothesis is rejected and alternative hypothesis $\mathrm{H} 1$ is accepted, which state that reliability of digital information has positive impact on customer buying decision, has been proved, so hypothesis 1 is correct. This study also show that easy access of websites is important factor which influence customer for using digital platform and some other factors like price, quality of the product and availability of product play important role and influence customers. Chi square value of hypothesis $\mathrm{H} 2$ is 8.22 , which is greater than $\mathrm{p}$ value, it means null hypothesis is rejected and alternative hypothesis is accepted so Influencing factors like quality, easy access of websites, price, and product availability has a positive impact on customer buying decision.

\section{REFERENCES}

[1] García, J., Lizcano, D., Ramos, C., \& Matos, N. (2019). Digital Marketing Actions That Achieve a Better Attraction and Loyalty of Users: An Analytical Study. Future Internet. Retrieved from http://www.mdpi.com/journal/futureinternet

[2] Anon,(2019).[online]Availableat:https://www.researchgate.net/publication/327903375_Pengar uh_Personalisasi_Iklan_Online_Terhadap_Sikap_Dan_Minat_Beli_Konsumen

[3] S. Sivasankaran (2017) Digital marketing and its impact on buying behavior of youth, Vol-4, Issue-3

[4] D.M Arvind Mallik (2017) Impact of digital marketing on youth buying behavior at Big Bazaar in Udupi, Vol-3, Issue-8.

[5] Upasan Kanchan (2015). A study of online purchase behavior of Consumers in India, ICTACT Journal of management Studies, Vol.01, Issue.03.

[6] Shalaka Ayarekar(2015), impact And Effectiveness Of Social Media Advertising on Young Working Women's Buying Behaviour with Reference to Consumer Electronics - A Study of Selected Cities in Maharashtra and Gujarat.

[7] Ashley, C., \& Tuten, T. (2015). Creative strategies in social media marketing: An exploratory study of branded social content and consumer engagement. Psychology \& Marketing, 32(1), 1527. https://doi.org/10.1002/mar.20761 
[8] Elisabeta Ioanăs (2014), Social Media And Its Impact On Consumers Behavior, International Journal of Economic Practices and Theories, Vol. 4, No. 2, 2014, Special Issue on Marketing and Business Development.

[9] Overview of Online Marketing, Failte Ireland, NTDA. 2 April 2012, Version 1.0.

[10] Philip Kotler (2003), Marketing Management, 11th Edition, Pearson Education

[11] Mohammed R. (2001), “internet marketing.” Mc Graw Hill, New York, Vol. 4.

[12] Mckinsey. (2009), “The consumer Decision Journey.” Mckinsey and Company. 